\title{
Effect of Green Tea and Vitamin C on Rheumatoid Arthritis of Male Albino Rat Induced with Collagen II
}

\author{
Mona F-EL-Karn*, Abdel-Raheim M. Meki**, \\ and Hafez R. H. Madkor *** \\ Departments of Physiology * and Biochemistry**\&***, Faculty of \\ Medicine*\&** and Faculty of Pharmacy***, \\ Assiut University*\&** and Al-Azhar University***, Assiut, Egypt
}

\begin{abstract}
In the present study, the biochemical effects of vitamin $C$, and aqueous extract of green tea (GTE) on rheumatoid arthritis (RA) of rats were investigated. The oxidative stress indices and the antioxidant levels were evaluated. Forty albino male rats were divided into four groups (10 rats each): control group, collagen II -induced $R A$ group (C II group), CII group treated with vitamin C (C II + Vit. C), and CII group treated with green tea extract (GTE) (C II + GTE). After 6 weeks of antioxidants treatment, the plasma levels of lipid peroxides (LPO), nitric oxide (NO), ceruloplasmin (PC), and glutathione (GSH) were detected using colorimetric methods. The plasma levels of copper $(\mathrm{Cu})$ and zinc $(\mathrm{Zn})$ were determined using atomic absorption/flame emission spectrometer. In C II treated group, the levels of $L P O, N O, C P$ and $\mathrm{Cu}$ were significantly higher but the levels of; GSH and $\mathrm{Zn}$ were significantly lower than controls. The levels of GSH and Zn were significantly increased but the levels of $\mathrm{NO}, \mathrm{Cu}$ and $\mathrm{CP}$ were significantly decreased in the vitamins $C$ treated groups in comparison with C II -treated group. In the C II + GTE group, the levels of $L P O, N O, C P$ and $\mathrm{Cu}$ were significantly decreased but the levels of GSH, and $\mathrm{Zn}$ were significantly increased in comparison with C II -treated group. The present study suggests that proper antioxidants intake may reduce free radical generation and improve antioxidant status in RA. GTE and vitamin C may effectively normalize in different degrees the impaired oxidant/ antioxidant system and may be useful in delaying the complication of RA.
\end{abstract}

\section{INTRODUCTION}

Rheumatoid arthritis (RA) is a polyarticular disease affecting about 1 $\%$ of the population of the world ${ }^{1}$. It is an autoimmune disease characterized by chronic inflammation, progressive joint destruction, physical impairment, work disability and early mortality ${ }^{2}$. The process of disease progression is characterized by hyperplasia of synoviocytes, mainly of synovial fibroblasts, resulting in bone and joint destruction $^{\mathbf{3}, \mathbf{4}}$. However, the proliferation of synovial cells is not limitless and spontaneous suppression of synovial proliferation has been observed $^{5}$.

Immunization of mice with collagen II (CII) leads to the development of arthritis "the collagen-induced arthritis model for RA". CII-specific activation of both $\mathrm{T}$ 
and B cells is critical for the development of arthritis and the transfer of both rodent and human serum with CII-specific antibodies induces arthritis in mice ${ }^{6,7}$.

Inflammation is known to result in increased production of nitric oxide (NO) and prostaglandins ${ }^{8}$. NO is an important mediator of diverse physiologic and pathologic processes, including arthritis 9 Joint inflammation in autoimmune adjuvant-induced arthritis is dependent on the enhanced production of NO.

McCartney-Francis et al. ${ }^{\mathbf{1 0}}$ (1999) reported that NO is ideally suited as a potent inflammatory mediator because of its strong reactivity with oxygen, superoxide, and ironcontaining compounds.

Several lines of evidence suggest that oxidative stress has a role in the pathology of RA. This oxidative stress, associated with the generation of free radicals, is a major contributor to joint damage in $\mathrm{RA}^{\mathbf{1 1}}$. The insufficiency of antioxidant defense systems and the acceleration of the oxidative reactions can result from the pro-oxidant/antioxidant imbalance in $\mathrm{RA}^{\mathbf{1 2}}$. It was demonstrated that the level of free radical-induced damage to proteins in the synovial fluid was twice as high in $\mathrm{RA}^{\mathbf{1 3}}$. Moreover, it was found that individuals with initially low levels of protecting antioxidants in their plasma, such as vitamins $\mathrm{C}$ and selenium, are at greater risk of developing $\mathrm{RA}^{\mathbf{1 4}}$.

The two most often suggested mechanisms for the increased incidence and activity of free radicals in RA joints are: (i) the production of various free radicals, such as superoxide, hydroxyl and hypochlorus by the invading phagocytes $^{15}$; and (ii) an increase in the intra-articular pressure above the synovial capillary perfusion pressure, causing intra-articular hypoxia. On cessation of exercise of the RAinflamed joint, an injurious reperfusion mechanism occurs, resulting in oxidative damage to lipids and immunoglobulin within the joint $^{16}$.

Zinc $(\mathrm{Zn})$ is a crucial element in a series of cellular functions as normal growth, protein metabolism, membrane stability, and metalloenzyme functions ${ }^{17}$. In addition, $\mathrm{Zn}$ has several other effects on immune response, complement system, lysozomal enzyme release, and macrophage functions ${ }^{\mathbf{1 8}}$. $\mathrm{Zn}$ is indispensible in many steps of the inflammatory reactions. Among these are prostaglandin biosynthesis, stimulation of lymphocytes and immune response, and scavenging of toxic free oxygen radicals. $\mathrm{Zn}$ is likewise an important element in collagen tissue formation and bone metabolism $^{\mathbf{1 8}}$

Copper $(\mathrm{Cu})$ is abundant in the human body and nature ${ }^{19} . \mathrm{Cu}$ is incorporated into the structure of many enzymes and proteins ${ }^{\mathbf{1 8}}$. It is reported that 30 to $50 \%$ increases in serum $\mathrm{Cu}$ level during an acute phase response triggered by interleukin -1 (IL-1) release largely depend upon the increased synthesis of ceruloplasmin (CP). It is demonstrated that $\mathrm{CP}$ increases during acute phase reactions in order to scavenge toxic free oxygen radicals ${ }^{20}$.

Inflammation within tissues induces a series of anti-inflammatory 
responses in which a number of proteins and enzymes carrying $\mathrm{Zn}$ and $\mathrm{Cu}$ elements are involved. Most notable among these are; metallothioneins, $\mathrm{CP}$, and superoxide dismutase $(\mathrm{SOD})^{\mathbf{2 1}}$. Intracytoplasmic SOD includes both $\mathrm{Cu}$ and $\mathrm{Zn}$, while $\mathrm{CP}$ is a powerful antioxidant in serum carries only $\mathrm{Cu}^{19}$. Substantial alterations in metabolisms of $\mathrm{Cu}$ and $\mathrm{Zn}$ occur through some physiological control mechanisms over an inflammatory reaction ${ }^{17}$

$\mathrm{CP}$ is a major protein that circulates in the plasma and functions as a copper transporter that is able to couple and transport 90-95\% of serum copper. It has been shown that this protein has antioxidant functions, which can prove beneficial in several pathological conditions ${ }^{22}$. CP is an acute-phase protein with a moderate reaction, an up to 2- or 3-fold increase, in inflammatory conditions. $\mathrm{CP}$ is mainly synthesized in hepatocytes and is secreted in plasma with six copper atoms strongly coupled to the molecule. CP and the copper are modified in parallel during inflammatory disease. This seems to indicate a linked mediation or a coordinated regulation of $\mathrm{CP}$ and serum copper ${ }^{23}$.

Some functions of $\mathrm{CP}$ can be inactivated by exposure to the free oxygen radical (FR) flux generated by the hypoxantine/xantine oxidase system (Giurgea et al., 2005). A significant inactivation of $\mathrm{CP}$ occurs during oxidative stress, this phenomenon being associated with the uncoupling of copper atoms from the CP molecule The antioxidant activity of $\mathrm{CP}$ has been reported in several studies, and there are reasons to believe that this is one of the most important functions of $\mathrm{CP}$ during inflammatory and acute-phase reactions ${ }^{23}$.

Recent animal studies strongly suggest anti-inflammatory role of antioxidants like SOD and vitamin $\mathrm{C}$ in experimentally induced arthritis. Antioxidant therapy strategies have been proposed for the prevention and treatment of RA (Mahajan and Tandon, 2004). Various forms of antioxidant therapy have demonstrated promising results in experimental RA models ${ }^{25-27}$.

Herbal medicines derived from plant extracts are being increasingly utilized to treat a wide variety of clinical disease ${ }^{28}$. More attention has been paid to the protective effects of natural antioxidants against compounds-induced free radical generation $^{29}$. Flavonoids have been found to play important roles in the non-enzymatic protection against oxidative stress ${ }^{30}$. Flavonoids are group of polyphenolic compounds that occur widely in fruit, vegetables and tea ${ }^{31}$. Fresh tea leaves are rich in flavanol monomers known as catechins such as epicatechins, which are $13.6 \mathrm{~g} / 100 \mathrm{~g}$ in green tea and 4.2 $\mathrm{g} / 100 \mathrm{gm}$ dry weight in black tea ${ }^{32}$. Supplementation of green tea extract (GTE) attenuates cyclosporine Ainduced oxidative stress in rats. Moreover, GTE can be reduced the risk of colorectal inflammatory disease and muscle necrosis ${ }^{33}$.

Aim of work:

The present study was aimed to investigate the effect of antioxidants as vitamin $C$ and GTE on rat model of RA. So, the plasma levels of lipid 
peroxides, NO, glutathione (GSH), $\mathrm{CP}, \mathrm{Cu}$ and $\mathrm{Zn}$ were determined.

\section{MATERIAL \& METHODS}

\section{Chemicals:}

L-Ascorbic acid, thiobarbituric acid, reduced glutathione, naphthylenediamine dihydrochloride, sulphanilamide, sodium nitrite, sodium azide, 5,5-dithio bis (2nitrobenzoic acid), epinephrine and $\mathrm{p}$ phenylene diamine dihydrochloride, complete Freund's adjuvant (CFA) and incomplete Freund's adjuvant (IFA) were fine grade and obtained from Sigma-Aldrich (St. Louis, MO, USA). All other chemicals used were of analytical grade.

\section{Animal treatment}

Forty healthy male albino rats (Rattus norvegicus) their body weight 150-170 gm were included in the present study. All animals were conditioned at room temperature at natural photoperiod for 1 week before the start of the experiment. A commercial balanced diet and tap water were provided. The duration of experiment was 45 days. They were randomly divided into 4 groups (10 rats each) as the following:-

1)Control Group (Normal group) served as a negative control.

2)Adjuvant Arthritic group (CII group) served as positive control. Bovine collagen type II (CII) was dissolved in $0.01 \mathrm{~N}$ acetic acid and emulsified in an equal volume of complete Freund's adjuvant (CFA) containing $1 \mathrm{mg} / \mathrm{ml}$ heat-killed Mycobacterium tuberculosis (Sigma-Aldrich). Rheumatoid arthritis was induced by the initial immunization with $100 \mu \mathrm{g} / 100 \mu \mathrm{l}$ emulsion by an intradermal injection in the base of the tail. Twenty one days later after the initial immunization, the rats received a booster intradermal injection (base of the tail) of $100 \mu \mathrm{g} / 100 \mu \mathrm{l}$ of bovine CII emulsified in incomplete Freund's adjuvant (IFA) ${ }^{34}$.

3)CII + vitamin $C$ - treated group (CII+ Vit. C group) was injected by $\mathrm{CII}$, and received vitamin $\mathrm{C}$ daily via oral route $(50 \mathrm{mg} / \mathrm{kg} / \text { day/oral })^{35}$ from the beginning of CII injection for 45 days.

4) CII + GTE - treated group (CII+ GTE group) was injected with CII, and received GTE from the beginning of CII injection for 45 days. The GTE was made according to Maity et al., $(1998)^{\mathbf{3 6}}$, by soaking $15 \mathrm{~g}$. of instant green tea powder in $1 \mathrm{~L}$ of boiling distilled water for 5 minutes. The solution was filtered to make $1.5 \%$ GTE. This solution was provided to rats as their sole source of drinking water.

All the tested antioxidants (vitamin $\mathrm{C}$ and GTE) were administrated daily for 45 days (experiment duration). The animals of different groups were sacrificed under light anesthesia 1 day after the end of the treatment. The blood samples from all groups were collected from the orbital vein in heparinized tubes and were centrifuged at $5000 \mathrm{rpm}$ for 10 min for plasma separation. Plasma samples were divided into aliquots and kept at $-40{ }^{\circ} \mathrm{C}$ until biochemical analysis.

\section{Biochemical analysis}

The plasma levels of lipid peroxides (LPO) were measured as 
thiobarbituric acid reactivity (TBARS). The product of the reaction between malondialdehyde and thiobarbituric acid was measured as described elsewhere ${ }^{37}$. The plasma levels of nitric oxide (NO) was determined as total nitrite after deproteinization with $\mathrm{ZnSO}_{4}(30 \%)$, nitrate reduction with cadmium (activated by $2 \% \mathrm{HCl}$ ) and color developed by the reaction with Griess reagent $(1 \%$ sulfanilamide/ $\quad 0.1 \%$ naphthylethylene diamine $\mathrm{diHCl}, \mathrm{w} / \mathrm{v}$ in $2.5 \% \quad \mathrm{H}_{3} \mathrm{PO}_{4}$ ) was recorded at $550 \mathrm{~nm}$ against reagent blank using sodium nitrite as standard ${ }^{\mathbf{3 8}}$. The plasma GSH levels were determined chemically as described by Ellman $(1959)^{39}$. The plasma CP activity was determined using a paraphenylenediamine dihydrochloride $\operatorname{method}^{\mathbf{4 0}}$. The plasma levels of zinc and copper were determined by employing flame atomic absorption spectrometry. The specific cathode lamps were used. Three determinations were made for each solution. The accuracy and precision of the analytical methods were tested with standard reference materials.

\section{Statistical analysis}

The results were expressed as mean \pm standard error (SE). Differences between groups were assessed by one-way analysis of variance (ANOVA) using the Prism version 4 software packages for Windows. The level of significance was accepted with $\mathrm{P}<0.05$.

\section{RESULTS}

Table (1) shows the measured bioindices in different treated rat groups compared with control group.

Fig. (1) shows the plasma levels of: (A) Copper, (B) Ceruloplasmin in different rat groups.

Rat group with rheumatoid arthritis: In the C II group, the levels of LPO, $\mathrm{NO}, \mathrm{CP}$ and $\mathrm{Cu}$ were significantly higher than controls. Contrarily, the levels of, GSH and $\mathrm{Zn}$ were significantly lower than controls.

Vitamins C effect: In the C II + Vit. C group, the levels of LPO, NO, CP and $\mathrm{Cu}$ were significantly increased but the levels of $\mathrm{Zn}$ were significantly decreased in comparison with controls. GSH levels showed non significant increase when compared with that of controls.

In comparison with C II -treated group, the levels of GSH and $\mathrm{Zn}$ were significantly increased but the levels of $\mathrm{NO}, \mathrm{Cu}$ and $\mathrm{CP}$ were significantly decreased in the C II + Vit.C group. Also, the levels of LPO were insignificantly decreased in vitamin $\mathrm{C}$ treated groups in comparison with the C II- treated group.

GTE effect: In the C II + GTE group, the levels of LPO, $\mathrm{NO}$, and $\mathrm{Cu}$ were significantly increased but the levels of GSH, CP and $\mathrm{Zn}$ did not show significantly changes in comparison with controls.

In comparison with C II -treated group, the levels of, LPO, NO, CP and $\mathrm{Cu}$ were significantly decreased but the levels of GSH, and $\mathrm{Zn}$ were significantly increased. 
Table (1) Comparison of plasma levels of bioindices among different treated rat groups and control groups.

\begin{tabular}{|c|c|c|c|c|c|c|c|c|c|c|}
\hline \multirow[t]{2}{*}{ Parameters } & \multirow{2}{*}{$\begin{array}{l}\text { (A) } \\
\text { Controls }\end{array}$} & \multirow{2}{*}{$\begin{array}{l}\text { (B) CII- } \\
\text { treated } \\
\text { Group }\end{array}$} & \multirow[b]{2}{*}{$\begin{array}{l}\text { (C) CII } \\
+ \\
\text { vitamin } \\
\text { C- } \\
\text { treated } \\
\text { group }\end{array}$} & \multirow{2}{*}{$\begin{array}{l}\text { (D) CII } \\
+ \text { GTE- } \\
\text { treated } \\
\text { group }\end{array}$} & \multicolumn{6}{|l|}{ P-Value } \\
\hline & & & & & A vs B & A vs $\mathrm{C}$ & A vs D & B vs C & B vs D & C vs D \\
\hline LPO (nmol/ml) & $\begin{array}{l}3.218 \pm \\
0.441\end{array}$ & $\begin{array}{l}8.000 \pm \\
1.193\end{array}$ & $\begin{array}{l}5.626 \pm \\
0.526\end{array}$ & $\begin{array}{l}5.182 \pm \\
0.485\end{array}$ & $<0.01$ & $<0.01$ & $<0.01$ & $\begin{array}{l}>0.05 \\
\mathrm{NS}\end{array}$ & $<0.05$ & $\begin{array}{l}>0.05 \\
\mathrm{NS}\end{array}$ \\
\hline NO (ng/ml) & $\begin{array}{l}3.619 \pm \\
0.215 \\
\end{array}$ & $\begin{array}{l}8.520 \pm \\
1.248 \\
\end{array}$ & $\begin{array}{l}4.629 \pm \\
0.091 \\
\end{array}$ & $\begin{array}{l}5.275 \pm \\
0.151 \\
\end{array}$ & $<0.001$ & $<0.001$ & $<0.001$ & $<0.01$ & $<0.05$ & $<0.01$ \\
\hline GSH (nmol/ml) & $\begin{array}{l}4.265 \pm \\
0.249\end{array}$ & $\begin{array}{l}2.749 \pm \\
0.306\end{array}$ & $\begin{array}{l}4.330 \pm \\
0.366\end{array}$ & $\begin{array}{l}4.242 \pm \\
0.184\end{array}$ & $<0.01$ & $\begin{array}{l}>0.05 \\
\mathrm{NS}\end{array}$ & $\begin{array}{l}>0.05 \\
\mathrm{NS}\end{array}$ & $<0.01$ & $<0.001$ & $\begin{array}{l}>0.05 \\
\mathrm{NS}\end{array}$ \\
\hline Copper ( g/ml) & $\begin{array}{l}2.374 \pm \\
0.098 \\
\end{array}$ & $\begin{array}{l}3.645 \pm \\
0.166 \\
\end{array}$ & $\begin{array}{l}3.268 \pm \\
0.064 \\
\end{array}$ & $\begin{array}{l}2.892 \pm \\
0.083 \\
\end{array}$ & $<0.001$ & $<0.001$ & $<0.001$ & $<0.05$ & $<0.001$ & $<0.01$ \\
\hline $\mathbf{C P}(\mathrm{mg} / \mathrm{dl})$ & $\begin{array}{l}95.860 \pm \\
11.320 \\
\end{array}$ & $\begin{array}{l}225.500 \pm \\
13.090\end{array}$ & $\begin{array}{l}166.700 \\
\pm 13.070 \\
\end{array}$ & $\begin{array}{l}103.600 \\
\pm 11.960 \\
\end{array}$ & $<0.001$ & $<0.001$ & $\begin{array}{l}>0.05 \\
\mathrm{NS}\end{array}$ & $<0.001$ & $<0.001$ & $\begin{array}{l}>0.05 \\
\mathrm{NS}\end{array}$ \\
\hline Zinc ( $\mathrm{g} / \mathrm{ml})$ & $\begin{array}{l}3.862 \pm \\
0.4147 \\
\end{array}$ & $\begin{array}{l}0.706 \pm \\
0.0515\end{array}$ & $\begin{array}{l}1.159 \pm \\
0.194\end{array}$ & $\begin{array}{l}4.151 \pm \\
0.308\end{array}$ & $<0.001$ & $<0.001$ & $\begin{array}{l}>0.05 \\
\mathrm{NS}\end{array}$ & $<0.05$ & $<0.001$ & $<0.001$ \\
\hline
\end{tabular}

Values are means $\pm \mathrm{SE}$ for 10 rats $(\mathrm{N}=10$ for each group).

The level of significance was accepted with $\mathrm{P}<0.05$. 


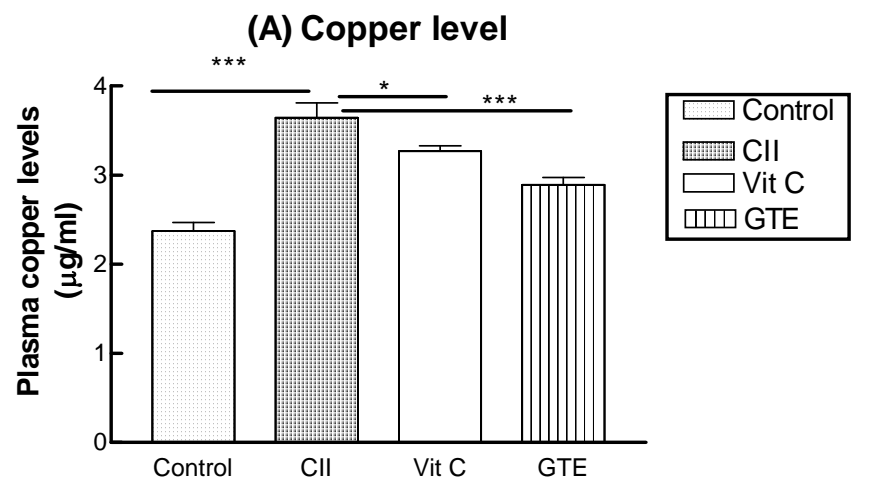

(B) Ceruloplasmin level

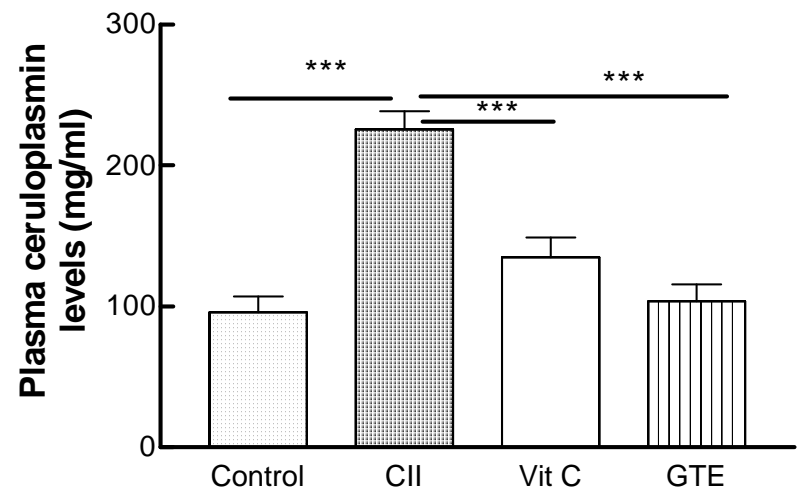

Fig. (1) shows the plasma levels of: (A) Copper and (B) Ceruloplasmin in different rat groups

\section{DISCUSSION}

Rheumatoid arthritis is an autoimmune disease that causes chronic inflammation of the joints and tissue around the joints with infiltration of macrophages and activated $\mathrm{T}$ cells ${ }^{41}$. The pathogenesis of that disease is linked predominantly with the formation of free radicals at the site of inflammation. Previously, Heliovaara et al., ${ }^{14}$ reported that a low antioxidant level is a risk factor for RA.

The present study was performed to evaluate the effect of antioxidants 
on RA rats and to assess oxidative stress markers in the blood. Recent investigations have consistently indicated that the inflammatory process produces oxygen radicals and decreased antioxidant levels, which may worsen the symptoms of the RA (Darlington and Stone ${ }^{\mathbf{4 2}}$ ).

Lipid peroxidation has been implicated in the pathogenesis of degenerative diseases and inflammatory arthritis ${ }^{43}$. During lipid peroxidation, polyunsaturated fatty acids are oxidized to produce lipid peroxyl radicals that in turn lead to further oxidation of polyunsaturated fatty acid in a perpetuating chain reaction that can lead to cell membrane damage. Matrix degradation arising from cytokinestimulated chondrocytes was shown to be primarily due to lipid peroxidation and to be preventable by vitamin $\mathrm{E}$, the primary antioxidant for $\operatorname{lipids}^{44}$.

Oxidative injury and inflammatory status in various rheumatic diseases was reported ${ }^{\mathbf{4 5}}$. In the current work, the levels of LPO, and $\mathrm{NO}$ in RA rat group were significantly higher than controls but NO levels were significantly reduced in all antioxidants (Vit C -, and GTE - ) - treated groups. Moreover, levels of LPO were significantly reduced in GTE-treated groups. Similarly, the levels of plasma LPO were found to be significantly higher in RA than controls in many previous studies ${ }^{\mathbf{4 6 , 4 7}}$. Fermor et al. ${ }^{48}$ suggested that many factors such as inflammation and mechanical loading in RA can lead to increased production of inflammatory mediators such as NO and prostaglandins (PGE2). Mahajan and
Tandon $^{24}$ have demonstrated the increased NO and LPO levels in RA. They proposed antioxidant therapy strategies for the prevention and treatment of RA. Jaswal et al., ${ }^{49}$ and Rennie et al., ${ }^{\mathbf{5 0}}$ found that vitamins E and $\mathrm{C}$ supplementation increase significantly the levels of antioxidants and decrease the concentration of LPO along with improved symptoms of RA.

Tariq et al., ${ }^{\mathbf{5 1}}$ reported that an antioxidant rich polyphenolic fraction isolated from green tea possesses antiinflammatory effects in experimental animals. In addition, many investigators suggested that GTE has antioxidants and scavenge free radicals actions ${ }^{\mathbf{5 2}}$. Singh et al., ${ }^{\mathbf{5 3}}$ noticed that the green tea inhibits production of $\mathrm{NO}$ in human chondrocytes. Furthermore, green tea is shown to reduce inflammation in arthritis and is rich in antioxidants which may be useful in the prevention of onset and severity of RA (Tariq et al., ${ }^{51}$ and Adcoks et al., ${ }^{54}$ ). Moreover, the reduction of $\mathrm{NO}$ and $\mathrm{PGE}_{2}$ by GTE in RA were also shown in some studies $^{53,55,56}$.

Haqqi et al., ${ }^{57}$ found that the potential disease-modifying effect of green tea on arthritis came to light when it was shown that collagen type II-induced RA (C II RA) in mice, was ameliorated by prophylactic administration of green tea polyphenols in drinking water. The reduced $C$ II $R A$ incidence and severity was reflected in a marked inhibition of the inflammatory mediators COX2, interferon-gama and tumor necrosis factor - alpha (TNF- $\alpha$ ) in arthritic joints of green tea-fed mice. Since increasing $\mathrm{PGE}_{2}$ 
can cause inflammatory reactions, such as local congestion, edema, and pain in rheumatoid arthritis, the significant decrease of $\mathrm{PGE}_{2}$ in rheumatoid rats may be due to inhibition of COX2 activity following the administration of GTE ${ }^{\mathbf{5 8 , 5 9}}$.

An increase in the in vivo generation of oxidants and lipid peroxidation products in the plasma of RA was found to be negatively correlated with the antioxidant levels ${ }^{\mathbf{6 0}}$.

Ceruloplasmin (CP) is considered the principal plasma and synovial antioxidant in RA, being responsible for up to $70 \%$ of the protective capacity against superoxide free radicals $^{61}$, which have been shown to be directly related to the pathogenesis of the inflamed joint in RA and the related increases in lipid peroxidation, ascorbate depletion and hyaluronate degradation $^{62}$. The functions of $\mathrm{CP}$ include copper transport, iron metabolism, antioxidant defense, and involvement in angiogenesis and coagulation. It has been shown that $\mathrm{CP}$ catalyzes the oxidation of $\mathrm{Fe}^{2+}$ to $\mathrm{Fe}^{3+}$, with a catalytic cycle that involves four of the six atoms of copper associated to $\mathrm{CP}$, and uses dioxygen as an electron acceptor without the mediation of an incompletely reduced reactive oxygen species such as $\mathrm{O}_{2}{ }^{-}$or $\mathrm{H}_{2} \mathrm{O}_{2}{ }^{63}$. This activity as ferroxidase is increased during inflammation, infections, and other conditions, and these observations seem to suggest that there is a possibility that $\mathrm{CP}$ acts both as an antioxidant and an acute-phase reactant ${ }^{63}$.

In the present study, the levels of $\mathrm{CP}$ and $\mathrm{Cu}$ were significantly higher in C II group than control group. The levels of $\mathrm{CP}$ and $\mathrm{Cu}$ were significantly reduced in all groups treated with antioxidants Vit C- and GTE-groups. Similarly; many investigators found that the plasma levels of CP were significantly higher in RA than in controls ${ }^{46,47}$. Moreover, Amancio et al. ${ }^{64}$ found the significant increase of plasma $\mathrm{Cu}$ in RA. However, the increase in the antioxidant capacity produced by $\mathrm{CP}$ seems unable to cope with the RAinduced oxidative stress, and thus the induced lipid peroxidation is not fully prevented (as indicated by the increase in LPO values). The finding of raised $\mathrm{Cu}$ levels in the plasma is to be expected because of a concomitant rise of $\mathrm{CP}$, which is an acute phase reactant ${ }^{65}$. Increased levels of $\mathrm{CP}$ observed in the present study may be related to its scavenging action of superoxide radicals that are generated during the inflammatory process of RA.

Acute or chronic inflammatory processes cause an accumulation of copper in many organs, particularly in the inflamed areas ${ }^{66}$. Additionally, a number of biologically active extracellular polypeptides, including cytokines and angiogenic factors, which participate in the pathogenesis and development of inflammatory processes, are known to be involved in trace metal metabolism. Copper plays an important role in development and maintenance of the immune system ${ }^{66}$. Zoli et al. ${ }^{65}$ revealed that IL- $1 \beta$ and TNF- $\alpha$ levels significantly correlate with serum copper concentrations. In the recent study, in vivo, copper chelation with tetrathiomolybdate strongly repressed 
acute inflammation and onset of RA model through inhibition of mononuclear cell infiltration, and pannus formation ${ }^{67}$. Also, Brewer ${ }^{68}$ reported that anticopper therapy such as penicillamine has efficacy in RA.

Zinc is a metal antioxidant and it is required in over 200 enzymes and so deficiency is likely to affect a number of different systems. Zinc, like copper, is a component of $\mathrm{CuZn-}$ superoxide dismutase, an important antioxidant enzyme. Zinc has a stabilising effect on membranes possibly by displacing bound transition metal ions and thereby preventing peroxidation of membrane lipids ${ }^{69}$.

In the present study, the levels of $\mathrm{Zn}$ and GSH were significantly lower in C II group than control group. Moreover, the levels of $\mathrm{Zn}$ and GSH were significantly elevated in all groups treated with antioxidants Vitamin C- and GTE-groups in comparison with C II groups. Previously, Tuncer et al., ${ }^{\mathbf{7 0}}$ found plasma zinc levels were decreased significantly in RA. The authors suggested that low plasma $\mathrm{Zn}$ level in $\mathrm{RA}$ is one of the nonspecific features of inflammation. It has been postulated that low serum zinc may be caused by elevated IL-1 associated with $\mathrm{RA}^{\mathbf{1 9}}$. With acute inflammation, the acute phase response may move $\mathrm{Zn}$ into the liver and the reduced plasma concentration may not be indicative of overall deficiency ${ }^{71}$. It is unclear whether chronic cytokine release, as is seen in RA, causes a shift of $\mathrm{Zn}$ from one compartment to another or if there is a true $\mathrm{Zn}$ depletion.
GSH plays an important role in the protection of cells and tissue structures. Its role includes detoxification of xenibiotics, free radicals, peroxides and regulation of immune function ${ }^{72}$. The authors reported that low levels of GSH are implicated in RA. In addition, it is found that $\mathrm{Zn}$-deficient rats have lowered GSH concentrations ${ }^{73}$. This finding may explain the reduction of plasma level of GSH in RA in our study. Moreover, Miesel and Zuber ${ }^{74}$ suggested participation of xanthin oxidase in the depletion of serum GSH in RA. Also, Hassan et al. ${ }^{75}$ found that RA was associated with significant depletion in GSH levels.

In conclusion, the current study suggests proper antioxidant intake may reduce free radical generation and improve antioxidant status in RA. GTE and vitamin C may effectively normalize in different degrees the impaired oxidant/ antioxidant system and may be useful in delaying the complication of RA. These antioxidants display considerable potency in anti-inflammatory action. The anti-inflammatory activity of GTE was most likely comparable to other antioxidants. It could be recommend to give these antioxidants as a part of drug course of RA treatment.

\section{REFERENCES}

1. Carol, C. and Richard, B. (2007): Rheumatoid Arthritis: Explained with pictures..Adam, Newyork-Times Company, USA.

2. Weyand CM and Goronzy JJ (1997): Pathogenesis of 
rheumatoid arthritis. Med. Clin. North Am., 81(1):29-55.

3. Harris ED. (1990): Rheumatoid arthritis: pathophysiology and implications for therapy. New Engl. J. Med.; 322: 1277-89.

4. Klocke R, Mani AR, Moore KP, Blake DR, and Mapp PI. (2005): Inactivation of xanthine oxidoreductase is associated with increased joint swelling and nitrotyrosine formation in acute antigen-induced arthritis. Clin. Exp. Rheumatol.; 23(3):345-50.

5. Firestein GS, Yeo $M$, and Zvaifler NJ. (1995): Apoptosis in rheumatoid arthritis synovium. J. Clin. Invest. ;96(3):1631-8.

6. Nandakumar KS, Svensson L, and Holmdahl R. (2003): Collagen type II-specific monoclonal antibody-induced arthritis in mice: description of the disease and the influence of age, sex, and genes. Am. J. Patho.l; 163:1827-1837.

7. Hietala MA, Nandakumar KS, Persson L, Fahlen S, Holmdahl R, and Pekna $M$ (2004): Complement activation by both classical and alternative pathways is critical for the effector phase of arthritis. Eu.r J. Immunol.; 34:1208-1216.

8. Coleman JW. (2001): Nitric oxide in immunity and inflammation. Int. Immunopharmacol.; 1:1397-406.

9. Wallace JL. (2005): Nitric oxide as a regulator of inflammatory processes. Mem. Inst. Oswaldo. Cruz., 100:5-9.

10. McCartney-Francis NL, Song XY, Mizel DE, Wahl CL, and Wahl SM (1999): Hemoglobin protects from streptococcal cell wall-induced arthritis. Arthritis Rheum.,42:1119-1127.

11. Cimen MYB, C, Imen O* B, Kac,maz M, O* Zturk JS, Yorganciog lu and Durak II. (2000): Oxidant/antioxidant status of the erythrocytes from patients with rheumatoid arthritis. Clin Rheumatol.; 19:275-277.

12. Ozkan Y, Yardym-Akaydyn S, Sepici A, Keskin E, Sepici V, and Simsek B.(2007): Oxidative status in rheumatoid arthritis. Clin Rheumatol. , 26(1):64-68.

13. Mantle D, Falkous G, and Walker D. (1999): Quantification of protease activities in synovial fluid from rheumatoid and osteoarthritis cases: comparison with antioxidant and free radical damage markers. Clin. Chim. Acta, 284:45-58.

14. Heliovaara $M$, Knekt $P$, Aho $K$, Aaran RK, Alfthan G, and Aromaa A.(1994): Serum antioxidants and risk of rheumatoid arthritis. Ann. Rheum. Dis.; 53:51-3.

15. Babior BM. (2000): Phagocytes and oxidative stress. Am. J. Med.; 109:33-44.

16. Blake DR, Merry P, Unsworth J, Kidd BL, Outhwaite JM, Ballard R, Morris CJ, Gray L, and Lunec J.(1989): Hypoxicreperfusion injury in the inflamed human joint. Lancet 1(8633):28993.

17. Vallee BL and Falchuk KH. (1993): The biochemical basis of zinc physiology. Physiol Rev., 73(1):79-118. 
18. Milanino R, Frigo A, Bambara LM, Marrella M, Moretti U, Pasqualicchio M, Biasi D, Gasperini R, Mainenti L, and Velo GP (1993): Copper and zinc status in rheumatoid arthritis: studies of plasma, erythrocytes and urine, and their relationship to disease activity markers and pharmacological treatment. Clin. Exp. Rheumatol., 11:271-281.

19. Honkanen V, Konttinen YT, Sorsa T, Hukkanen M, Kemppinen P, Santavirta S, Saari H, and Westermarck $T$. (1991): Serum zinc, copper and selenium in rheumatoid arthritis.J. Trace Elem. Electrolytes Health Dis.; 5(4):261-3.

20. Kremer JM and Bigaoutte J. (1996): Nutrient intake of patients with rheumatoid arthritis is deficient in pyridoxine, zinc, copper, and magnesium. J. Rheumatol., 23:990-994.

21. Pandey SP, Bhattacharya SK, and Sundar S. (1985): Zinc in rheumatoid arthritis. Indian J. Med. Res., 81:618-620.

22. Halliwell B and Gutteridge JM. (1990): The antioxidants of human extracellular fluids. Arch. Biochem. Biophys.; 280: 1-8.

23. Giurgea N, Constantinescu MI, Stanciu R, Suciu S, and Muresan A. (2005): Ceruloplasmin - acute-phase reactant or endogenous antioxidant? The case of cardiovascular disease. Med Sci Monit.11 (2):RA48-51.

24. Mahajan $A$ and Tandon VR (2004): Antioxidants and rheumatoid arthritis. J. Indian Rheumatol Assoc. 12: 139-142.

25. Venkatraman JT, and Chu WC. (1999): Effects of dietary omega-3 and omega-6 lipids and vitamin $\mathrm{E}$ on serum cytokines, lipid mediators and anti-DNA antibodies in a mouse model for rheumatoid arthritis. J Am Coll Nutr, 18:602-613.

26. Cuzzocrea S, McDonald MC, Mota-Filipe H, Mazzon E, Costantino G, Britti D, Mazzullo G, Caputi AP, and Thiemermann C. (2000): Beneficial effects of tempol, a membrane-permeable radical scavenger, in a rodent model of collagen-induced arthritis. Arthritis Rheum.; 43:320-328.

27. Bandt MD, Grossin M, Driss F, Pincemail J, Babin-Chevaye C, and Pasquier C. (2002): Vitamin E uncouples joint destruction and clinical inflammation in a transgenic mouse model of rheumatoid arthritis. Arthritis Rheum.; 46:522-532.

28. Gupta, M., Mazumder, U., Kumar, T., Gomathi, P. and Kumar, R. (2004): Antioxidant and hepatoprotective effects of Buhinia racemosa against paracetamol and carbon tetrachloride induced liver damage in rats. Iranian J.. Pharma. Therapeutica 3: 12-20.

29. Frei. B. and Higdon, J. (2003) Antioxidant activity of tea polyphenols in vivo: evidence from animal studies. J. Nutr.; 133: 3275-3284.

30. Babich, H., Gold, T. and Gold, R. (2005): Mediation of the in 
vitro cytotoxicity of green tea and black tea polyphenols by cobalt chloride. Toxicol. (Lett.) 155, 195-205.

31. Matito, C., Mastoraku, F., Centelles, J., Torres, J. and Cascante, M. (2003): Antiproliferative effect of antioxidant polyphenols from grape in murine Heplc1c7. Eur. J. Nutr., 42:43-49.

32. Peterson, S., Dwyer, J., Bahgwat, S., Haytowitz, D., Holden, J., Eldridge, A., Beecher, G. and Aladesanmi, J. (2005): Major flavonoids in dry tea. J. Food Composition and Analysis 18:487-501.

33. Benelli, R., Vene, R., Bisacchi, D., Garbisa, S. and Albini, A. (2002): Anti-invasive effects of green tea polyphenol epigallocatechin-3-gallate, a natural inhibitor of metallo and serine protease. Biol. Chem.; 383, 101-105.

34. Hegen $M$, Gaeste $M$ and Telliez J-B. (2006): MAPKAP Kinase 2deficient mice are resistant to collagen-induced arthritis. J. Immunol... 177:1913-1917.

35. Eldin AA, Hamdy MA, Shaheen AA, Motawi TK, and Abd el Gawad HM. (1992): Effect of vitamin C administration in modulating some biochemical changes in arthritic rats.Pharmacol.Res.; 26(4):357-66.

36. Maity, S., Vadasiromoni, J. and Ganguly, D. (1998): Role of glutathione in the antiulcer effect of hot water extract of black tea. Jpn. J. Pharmacol., 78: 285-292.
37. Thayer, W.S. (1985): Serum lipid peroxides in rats treated chronically with adiramycine. Biochem. Pharmacol. ,33 (14): 2259-2263.

38. Van Beenooijen RL, QUE I, Ederveen AG, and Kloosterbor HJ (1988): Plasma nitrate + nitrite level are regulated by ovarian steroids but do not correlate with trabecular bone mineral density in rats. J. Endocrinol. 159: 27-34.

39. Ellman, G.L. (1959): Tissue sulfhydryl groups. Archives Biochem.. Biophys..; 82: 70-77.

40. Houchin, O.B. (1959): Clin.Chem. 4: 519-523. Quoted from: Practical Clinical Enzymology. King J., (ed.) Van Nostrand Company London 1177, 1959.

41. Bauerova $K$ and Bezek $A$. (1999): Role of reactive oxygen and nitrogen species in etiopathogenesis of rheumatoid arthritis. Gen. Physiol. Biophys. ; 18 (Spec No): 15-20.

42. Darlington LG and Stone TW (2001): Antioxidants and fatty acids in the amelioration of rheumatoid arthritis and related disorders. Br. J. Nutr.; 85:251269.

43. Kumar,V; Abul, KA.and Robins NF. and Cotran $M$. (2006): Pathologic basis of disease. Elsevier publisher, 71A/I,New Delhi,110024,India.

44. Tiku ML, Shah R, and Allison GT (2000): Evidence linking chondrocyte lipid peroxidation to cartilage matrix protein degradation. Possible role in cartilage aging and the 
pathogenesis of osteoarthritis. $J$. Biol. Chem, 275:20069-20076.

45. Bae SC, Kim SJ, and Sung MK. (2003): Inadequate antioxidant nutrient intake and altered plasma antioxidant status of rheumatoid arthritis patients. J. Am. Coll. Nutr.;. 22(4):311-5.

46. Kiziltunc A, Cogalgil S, and Cerrahoglu L. (1998): Carnitine and antioxidant levels in patients with rheumatoid arthritis. Scand J. Rheumatol; 27:441-5.

47. Ozturk HS, Cimen MY, Cimen OB, Kacmaz M, and Durak I. (1999): Oxidant/antioxidant status of plasma samples from patients with rheumatoid arthritis. Rheumatol Int. 19:35-7.

48. Fermor B, Christensen SE, Youn I, Cernanec JM, Davies CM, and Weinberg JB. (2007): Oxygen, nitric oxide and articular cartilage. Eur. Cell Mater. 13:5665.

49. Jaswal S, Mehta HC, Sood AK, and Kaur J. (2003): Antioxidant status in rheumatoid arthritis and role of antioxidant therapy. Clin. Chim. Acta, 338:123-129.

50. Rennie KL, Hughes J, Lang R, and Jebb SA. (2003): Nutritional management of rheumatoid arthritis: a review of the evidence. J. Hum. Nutr. Diet.. 16(2):97-109.

51. Tariq MH and Ahmad NK. (1999): Prevention of collageninduced arthritis in mice by a polyphennolic fraction from green tea. Immunology 96 (8): 4524-9.

52. Cooper R, Morre DJ, and Morre DM.(2005): Medicinal benefits of green tea :Part I.
Review of noncancer health benefits. J. Aten. Complement Med.;.11(3):521-8.

53. Singh $\mathbf{R}$, Ahmed $\mathrm{S}$, Islam $\mathbf{N}$, Goldberg VM, and Haqqi TM.(2002): Epigallocatechin-3gallate inhibits interleukin-1betainduced expression of nitric oxide synthase and production of nitric oxide in human chondrocytes: suppression of nuclear factor kappaB activation by degradation of the inhibitor of nuclear factor kappaB. Arthritis Rheum; 46(8):2079-86.

54. Adcocks C, Collin $P$, and Buttle DJ. (2002): Catechins from green tea (Camellia sinensis) inhibit bovine and human cartilage proteoglycan and type II collagen degradation in vitro. J. Nutr.; 132(3):341-6.

55. Ahmed S, Rahman A, Hasnain A, Lalonde M, Goldberg VM, and Haqqi TM. (2002): Green tea polyphenol epigallocatechin3-gallate inhibits the IL-1 induced activity and expression of cyclooxygenase- 2 and nitric oxide synthase-2 in human chondrocytes. Free Radic. Biol. Med.;33:1097-105.

56. Hagfors L, Leanderson $P$, Skoldstam L, Andersson J, and Johansson G. (2003): Antioxidant intake, plasma antioxidants and oxidative stress in a randomized, controlled, parallel, Mediterranean dietary intervention study on patients with rheumatoid arthritis. Nutr. J. 30; 2 (5): 1-11.

57. Haqqi TM, Anthony DD, Gupta S, Ahmad N, Lee MS, Kumar GK, and Mukhtar $H$. 
(1999): Prevention of collageninduced arthritis in mice by a polyphenolic fraction from green tea. Proc. Natl. Acad. Sc.;i USA 96:4524-4529.

58. Kontny E, Rudnicka W, Kowalczewski

Marcinkiewicz J, and Maslinski W. (2003): Selective inhibition of cyclooxygenase 2generated prostaglandin E2 synthesis in rheumatoid arthritis synoviocytes by taurine chloramines. Arthritis Rheum. , 48(6):1551-1555.

59. Fogel-Petrovic M., Long J.A., Knight D.A., Thompson P.J. and Upham J.W. (2004): Activated human dendritic cells express inducible cyclooxygenase and synthesize prostaglandin E2 but not prostaglandin D2, Immunological Cell Biology 82: 47-54.

60. Gambhir JK, Lali P, and Jain AK. (1997): Correlation between blood antioxidant levels and lipid peroxidation. Clin. Biochem.; 30::351-5.

61. Biemond P, Swaak AJG, and Koster JF. (1984): Protective factors against oxygen free radicals and hydrogen peroxide in rheumatoid arthritis synovial fluid. Arthritis Rheum.; 27:7605.

62. Halliwell B. (1995): Oxygen radicals, nitric oxide and human inflammatory joint disease. Ann. Rheum. Dis..; 54: 505-10.

63. Kang JH, Kim KS, Choi SY, Kwon HY, and Won MH. (2001): Oxidative modification of human ceruloplasmin by peroxyl radicals. Biochim. Biophys. Acta. ;1568(1):30-36.

64. Amancio SOM, Chaud A DM, Yanaguibashi G, and Esteves Hilario MO.(2003): Copper and zinc intake and serum levels in patients with juvenile rheumatoid arthritis. Eur. J. Clin. Nutr..; 57(5):706-12.

65. Zoli A, Altomonte L, Caricchio R, Galossi A, Mirone L, Ruffini MP, and Magaro M. (1998): Serum zinc and copper in active rheumatoid arthritis: correlation with interleukin 1 beta and tumour necrosis factor alpha. Clin. Rheumatol., 17:378-382.

66. Percival SS (1998): Copper and immunity. Am. J. Clin. Nutr., 67:1064-1068.

67. OmotoI A, Kawahito Y, Prudovsky I, Tubouchi Y, Kimura $M$, and Ishino $H$. (2005): Copper chelation with tetrathiomolybdate suppresses adjuvant-induced arthritis and inflammation-associated

cachexia in rats. Arthritis Research \& Therapy 7: R1174R1182

68. Brewer GJ (2005): Anticopper therapy against cancer and diseases of inflammation and fibrosis. Drug Discovery Today10: 1103-1109.

69. Evans $P$ and Halliwell $B$ (2001): Micronutrients: oxidant/antioxidant status. Br. J.Nut.; 85, (Suppl. 2): S67 \pm S74

70. Tuncer S, Kamanli A, Akcil E, Kavas GO, Seckin B, and Atay MB.(1999): Trace element and magnesium levels and superoxide dismutase activity in rheumatoid 
arthritis. Biol. Trace Elem. Res., 68(2):137-42.

71. Shenkin A. (1995): Trace elements and inflammatory response: implications for nutritional support. Nutrition; 11:110-15.

72. Ganesan N, Chegu H. and Chandrasekaran AN (2003): Effect of type II collagen treatment on the antioxidant status in immune tissues of adjuvant induced arthritic rats. Indian J. Clin. Biochem.; 18(2): 216-222.

73. Kraus A, Roth HP and Kirchgessner M (1997): Influence of vitamin $\mathrm{C}$, vitamin $\mathrm{E}$ and beta-carotene on the osmotic fragility and the primary antioxidant system of erythrocytes in zinc-deficient rats. Archives fur Tierernahrung 50: 257-269.

74. Miesel R, and Zuber M. (1993): Elevated levels of xanthine oxidase in serum of patients with inflammatory and autoimmune rheumatic diseases Inflammation. 17(5):551-61.

75. Hassan MQ, Hadi RA, Al-Rawi ZS, Padron VA, and Stohs SJ (2001): The glutathione defense system in the pathogenesis of rheumatoid arthritis. J. Appl. Toxicol. 21:69-73.

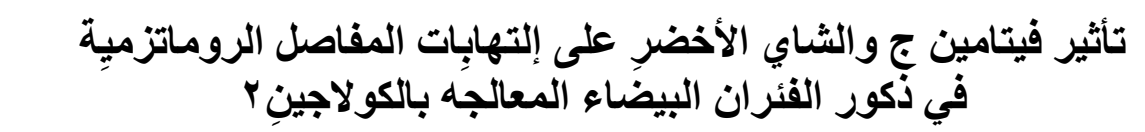

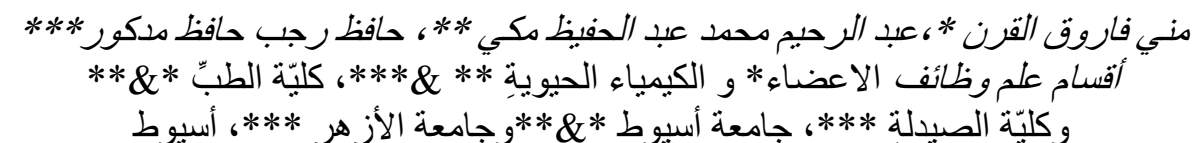

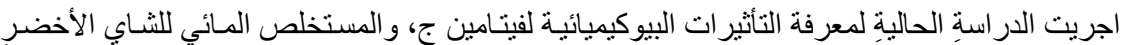

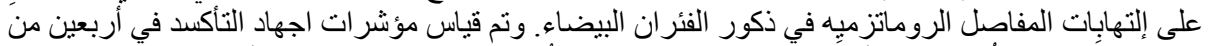

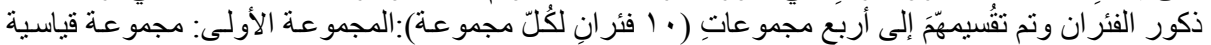

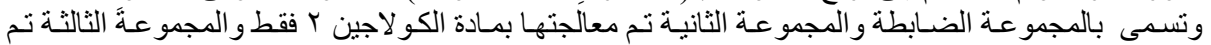

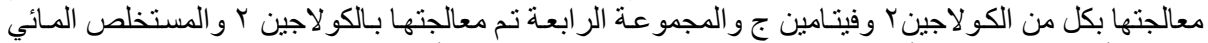

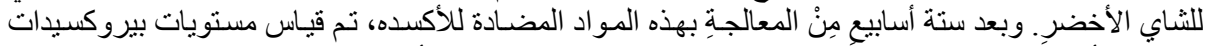

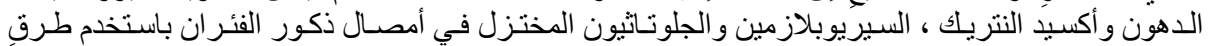

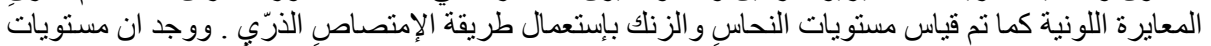

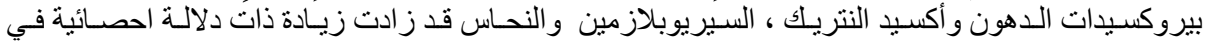

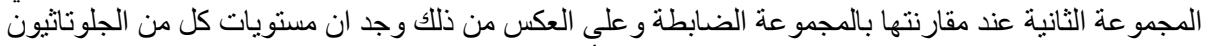

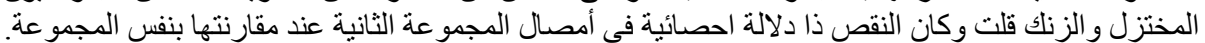

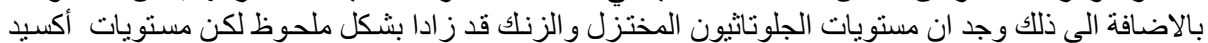

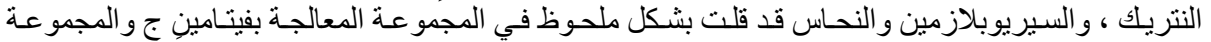

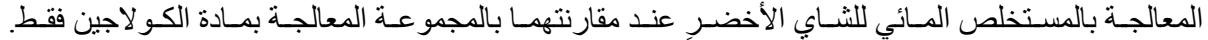

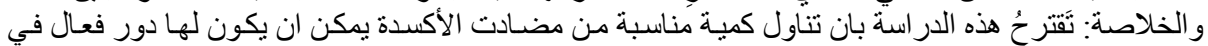

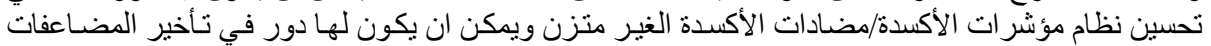

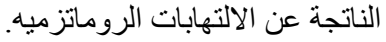

